\title{
River Sediment Analysis by Slurry Sampling FAAS: Determination of Copper, Zinc and Lead
}

\author{
Flávia L. Alves, Solange Cadore, Wilson F. Jardim and Marco A. Z. Arruda*
}

\author{
Instituto de Química, Universidade Estadual de Campinas, CP 6154, 13083-970, Campinas - SP, Brazil
}

\begin{abstract}
Foi desenvolvido um procedimento experimental para a análise direta de sedimento. Com o emprego deste procedimento, foram determinados cobre, zinco e chumbo, e foram conseguidas recuperações quantitativas para esses metais com baixo custo e manipulação mínima das amostras. Foram investigadas a influência da concentração do ácido nítrico no preparo da suspensão, bem como o tamanho de partícula do sedimento. As suspensões do sedimento foram tratadas com ácido nítrico 6,0 mol L-1 e cloreto de amônio $2 \%(\mathrm{~m} / \mathrm{v})$, e sonicadas por 15 minutos em um banho de ultrasom antes da quantificação por espectrometria de absorção atômica com chama. Empregando essas condições, a porcentagem de recuperação para cobre, zinco e chumbo foram 96,4 $\pm 4,9 ; 97,0 \pm 4,0$ e $99,7 \pm 4,0$, respectivamente, empregando-se um material certificado de referência.
\end{abstract}

An experimental procedure for direct sediment analysis was developed. Using this procedure, copper, zinc and lead were determined and quantitative recoveries for these metals were accomplished at a low cost and with minimal sample manipulation. The influence of the nitric acid concentration on the slurry preparation, as well as the sediment particle size was investigated. Sediment slurries were treated with $6.0 \mathrm{~mol} \mathrm{~L}^{-1}$ nitric acid and $2 \%(\mathrm{~m} / \mathrm{v})$ ammonium chloride, and sonicated for 15 minutes in an ultrasonic bath before quantification by flame atomic absorption spectrometry. Using these conditions for a certified reference material, the percentage of recovery for copper, zinc and lead were $96.4 \pm 4.9,97.0 \pm 4.0$ and $99.7 \pm 4.0$, respectively.

Keywords: river sediment, slurry atomisation, FAAS

\section{Introduction}

The availability of quantitative data on inorganic contaminants in river sediments is being recognised as a prerequisite to evaluate potential risks of inducing either long-term deficiency problems or unacceptable pollutant level accumulation that could result in deleterious effects to micro-organisms, higher plants and humans ${ }^{1-3}$.

At this matrix, routine analysis for metal determination is normally carried out by flame atomic absorption spectrometry (FAAS). The main reasons for that are its low operational costs, when compared to other techniques, and its easy operation ${ }^{4}$. However, this approach generally requires the complete dissolution of the sample before its introduction into the flame. This is usually much more timeconsuming than the FAAS measurement itself ${ }^{5}$. In many cases high blank values, or analyte losses are observed ${ }^{6}$. The sample preparation by conventional wet-oxidation or dry-ashing can also be a major problem due to time consuming and/or contamination ${ }^{7,8}$.

*e-mail: zezzi@iqm.unicamp.br
In order to avoid these drawbacks, sample introduction as slurry for different techniques can be an interesting approach. Recently, the direct analysis of solid samples has grown in popularity, offering some advantages over conventional procedures. The slurry sampling has received a great deal of attention and is described in several reviews ${ }^{9-11}$.

The slurry, a suspension prepared from finely powdered sample, seems to be an appropriate alternative for sample introduction. This sampling technique was developed by Brady et al. ${ }^{12,13}$. Its advantages are simplicity of sample treatment, reduction in sample preparation time and contamination, as well as the elimination of problems associated with sample handling ${ }^{14}$. An additional advantage is that the slurry concentration can be changed by dilution and the analyte concentration can be determined by the analytical curves ${ }^{11}$.

The determination of metals in slurred sediments, using the atomisation procedure with graphite furnace atomic absorption spectrometry, has already been used by some authors $6,7,14-16$

Flame atomic absorption spectrometry (FAAS) can also be used for metal determination in geological samples ${ }^{5}$. Fry and Denton ${ }^{17}$, who proposed the use of a special nebuliser 
to overcome this problem, observed the influence of the suspended particle sizes on the efficiency of the transference through the nebuliser. The use of discrete nebulisation instead of continuous aspiration of the sample, by means of flow injection, decreases the possibility of nebuliser clogging ${ }^{18}$. Thus, under appropriate conditions, the flame atomisation of slurries can be successfully used with different kinds of materials, as described in the literature ${ }^{19-22}$.

Despite the fact that sediment digestion using a microwave oven has received great attention in recent years, it has the inconvenience of high cost and demands special safety conditions. In addition, ASTM $^{23}$ recommends the use of nitric acid in order to leach elements not interstitially bound to silicate lattices. Nevertheless, this procedure may not be drastic enough to completely digest all kinds of sediments.

Based on these considerations, the aim of this work is to develop and validate a simple, fast, low cost and safe method for $\mathrm{Zn}, \mathrm{Cu}$ and $\mathrm{Pb}$ determinations in river sediments, using slurry sampling flame atomic absorption spectrometry. Such a procedure would make environmental studies, which require a great number of samples, easier to carry out.

\section{Experimental}

\section{Apparatus}

For $\mathrm{Cu}, \mathrm{Pb}$, and $\mathrm{Zn}$ determinations in slurries, liquid phase and digested samples, a Perkin-Elmer 5100 atomic absorption spectrometer (Norwalk, CT, USA), equipped with a deuterium background corrector and an impact bead nebuliser was used. The instrument parameters used were: slit of $0.7 \mathrm{~nm}, \mathrm{C}_{2} \mathrm{H}_{2}$ and air gas flow of 1.8 and $8.8 \mathrm{~L} \mathrm{~min}^{-1}$, respectively, for all elements and wavelengths of $324.8 \mathrm{~nm}$, $283.3 \mathrm{~nm}$ and $213.9 \mathrm{~nm}$, for $\mathrm{Cu}, \mathrm{Pb}$ and $\mathrm{Zn}$, respectively. Hollow cathode lamps (Perkin-Elmer, Darmstadt, Germany) of $\mathrm{Cu}, \mathrm{Zn}$ and $\mathrm{Pb}$ were used as radiation sources and the analytical measurements were based on time average absorbance.

A QCI microwave oven, Model QW-3000 (Mississauga, Canada), equipped with temperature and pressure sensors and a magnetron of $2450 \pm 13 \mathrm{MHz}$ with nominal power of $1200 \mathrm{~W}$ was used for sample preparation.

A Cole Parmer model 8890 ultrasonic bath (Vernon Hills, Illinois 60061, USA) was used for homogenisation of the slurry prior to its introduction into the nebuliser system.

Reagents, solutions and samples

All solutions were prepared with analytical quality chemicals (Merck, Darmstadt, Germany) and high purity de-ionised water $(18 \mathrm{M} \Omega \mathrm{cm})$ purified by a Milli-Q Water Purification System (Millipore, Bedford, USA) was used throughout. Nitric, hydrochloric, hydrofluoric and boric acids as well as ammonium chloride (analytical grade, Merck, Darmstadt, Germany) were also used.

A $1000 \mathrm{mg} \mathrm{L}^{-1}$ of $\mathrm{Zn}$ (II) [from $\mathrm{Zn}\left(\mathrm{NO}_{3}\right)_{2}$ ] and $\mathrm{Pb}$ (II) [from $\mathrm{Pb}\left(\mathrm{NO}_{3}\right)_{2}$ ] solutions were prepared as stock solutions. Copper stock solution was prepared from its metallic form (99.99\% purity). The standard solutions for $\mathrm{Cu}, \mathrm{Zn}$ and $\mathrm{Pb}$ were prepared daily by making serial dilutions with $6.0 \mathrm{~mol}$ $\mathrm{L}^{-1} \mathrm{HNO}_{3}$. The effect of concomitants was investigated in the presence of up to $1.5 \mathrm{mg} \mathrm{L}^{-1}$ of $\mathrm{Cr}(\mathrm{VI})$ from $\left[\mathrm{K}_{2} \mathrm{Cr}_{2} \mathrm{O}_{7}\right]$, up to $1.0 \mathrm{mg} \mathrm{L}^{-1} \mathrm{Ni}$ and $8.0 \mathrm{mg} \mathrm{L}^{-1} \mathrm{Mn}$ from their metallic form (99\% of purity), up to $800 \mathrm{mg} \mathrm{L}^{-1} \mathrm{Al}$ (III) from $\left[\mathrm{Al}\left(\mathrm{NO}_{3}\right)_{3}\right]$, up to $700 \mathrm{mg} \mathrm{L}^{-1} \mathrm{Ca}(\mathrm{II})$ from $\left[\mathrm{Ca}\left(\mathrm{NO}_{3}\right)_{2}\right]$, up to $130 \mathrm{mg} \mathrm{L}^{-1} \mathrm{Mg}$ (II) from [Mg(NO $\left.\left.\mathrm{NO}_{3}\right)_{2}\right]$, up to $290 \mathrm{mg} \mathrm{L}^{-1}$ $\mathrm{K}^{+}$from $\left[\mathrm{KNO}_{3}\right]$ and up to $700 \mathrm{mg} \mathrm{L}^{-1} \mathrm{Fe}$ (III) from $\left[\mathrm{Fe}\left(\mathrm{NO}_{3}\right)_{3}\right]$ and making the appropriate dilutions to approximately the sediment reference material concentrations. All solutions were prepared in $6 \mathrm{~mol} \mathrm{~L}^{-1}$ nitric acid and $2 \%(\mathrm{w} / \mathrm{v})$ ammonium chloride.

Sediment cores (up to $40 \mathrm{~cm}$ ) were sampled in February 1998, from the Atibaia River near to the Campinas city (State of S. Paulo, Brazil). The samples were kept in plastic bags at $4{ }^{\circ} \mathrm{C}$ and treated as follows: sieved in a $2 \mathrm{~mm}$ nylon sieve, dried in oven $\left(50{ }^{\circ} \mathrm{C}\right)$ to constant weight, then sieved again to obtain a $<63 \mu \mathrm{m}$ particle size for slurry preparation.

In order to evaluate the proposed method, the reference material (NIST SRM 1646a - Estuarine Sediment) was analysed in the following ways: (1) as slurry, (2) in the liquid phase after separation from the slurry and (3) in the mineralised samples by microwave oven.

\section{Slurry preparation}

An amount of $0.500 \mathrm{~g}$ of dried sample (particles $<63 \mu \mathrm{m}$ ) was weighed, an adequate amount of $\mathrm{NH}_{4} \mathrm{Cl}$ was added in order to obtain a final $2 \%(\mathrm{~m} / \mathrm{v})$ concentration, and $c a .20$ $\mathrm{mL}$ of a $6 \mathrm{~mol} \mathrm{~L}^{-1}(\mathrm{v} / \mathrm{v}) \mathrm{HNO}_{3}$ solution was added. This suspension was then sonicated in an ultrasonic bath for 15 min. Finally, the volume was adjusted to $25.0 \mathrm{~mL}$ and the final slurry was aspirated into the nebuliser for $\mathrm{Pb}, \mathrm{Zn}$ or $\mathrm{Cu}$ determination. In order to quantify these metals, analytical curves were performed using aqueous standards (prepared as previously described).

\section{Liquid phase sample preparation}

The liquid phase was obtained by filtering the sediment slurry (Whatman filter paper - fast speed), and it was analysed without any pre-treatment. 


\section{Sample mineralisation}

The following decomposition procedure was used: 0.500 $\mathrm{g}$ of dried sample was placed in a $100 \mathrm{~mL}$ Teflon flask and $15 \mathrm{~mL}$ of a digestion mixture [aqua regia: $\mathrm{HF}$ in a $2: 1(\mathrm{v} / \mathrm{v})$ ratio] was added. The microwave oven was operated using a five steps Power x Time program as follows: $200 \mathrm{~W}$ for 3 $\mathrm{min}, 400 \mathrm{~W}$ for $5 \mathrm{~min}, 600 \mathrm{~W}$ for $5 \mathrm{~min}, 700 \mathrm{~W}$ for $20 \mathrm{~min}$ and $80 \mathrm{~W}$ for $2 \mathrm{~min}$. The temperature and pressure limits were $190^{\circ} \mathrm{C}$ and 350 psi, respectively. After the digestion procedure, boric acid was added to eliminate $\mathrm{HF}$ and the solution was evaporated close to dryness. The volume was adjusted to $50 \mathrm{~mL}$ with a $2 \%(\mathrm{v} / \mathrm{v}) \mathrm{HNO}_{3}$ solution.

\section{Results and Discussion}

\section{Particle size and stability}

In order to optimise the slurry preparations the following parameters were investigated: sample homogeneity, slurry concentration and particle size ${ }^{10}$. Errors associated with slurry sampling can be minimised when working with small particles, concentrated slurries and narrow particle size distributions ${ }^{24}$. Considering the well-known fact that a large number of particles reduce sampling errors, it is advisable to obtain small particle size $^{25}$. According to some authors, the use of particle sizes smaller than $25 \mu \mathrm{m}$ leads to better results ${ }^{25}$. In this work particle sizes of $75,63,53$, and $38 \mu \mathrm{m}$ were studied after being obtained from stainless steel sieves. When employing $75 \mu \mathrm{m}$ particle size, a decrease in the analytical signals of $c a$. $50 \%$ was observed (Figure 1). Particles of $\leq 63 \mu \mathrm{m}$ did not show significant differences in their analytical signals. These results are in agreement with Klemm and Bombach ${ }^{6}$, who reported that, homogeneous and stable suspensions were obtained with particle sizes smaller than $63 \mu \mathrm{m}$. From this, the studies were carried out with a particle size of $63 \mu \mathrm{m}$.

The use of thixotropic agents, such as Triton X-10025,26, Viscalex ${ }^{27}$, glycerol ${ }^{28}$, and others, is recommended in order to stabilise and homogenise the slurry. In this work the presence of Triton X-100 did not improve the analytical signal. Using Estuarine Sediment $\left(2.47 \mathrm{~g} \mathrm{~cm}^{-3}\right)$ for slurry preparation in $6.0 \mathrm{~mol} \mathrm{~L}^{-1} \mathrm{HNO}_{3}$, a sample sedimentation of $c a .0 .18 \mathrm{~cm} \mathrm{~s}^{-1}$ was observed. Using only an ultrasonic bath (for $15 \mathrm{~min}$ ) and manual shaking immediately before the slurry nebulisation was enough to stabilise the suspension and obtain precise results (RSD ca. 5\%).

\section{Effect of nitric acid concentration}

According to the literature, the slurry can be prepared

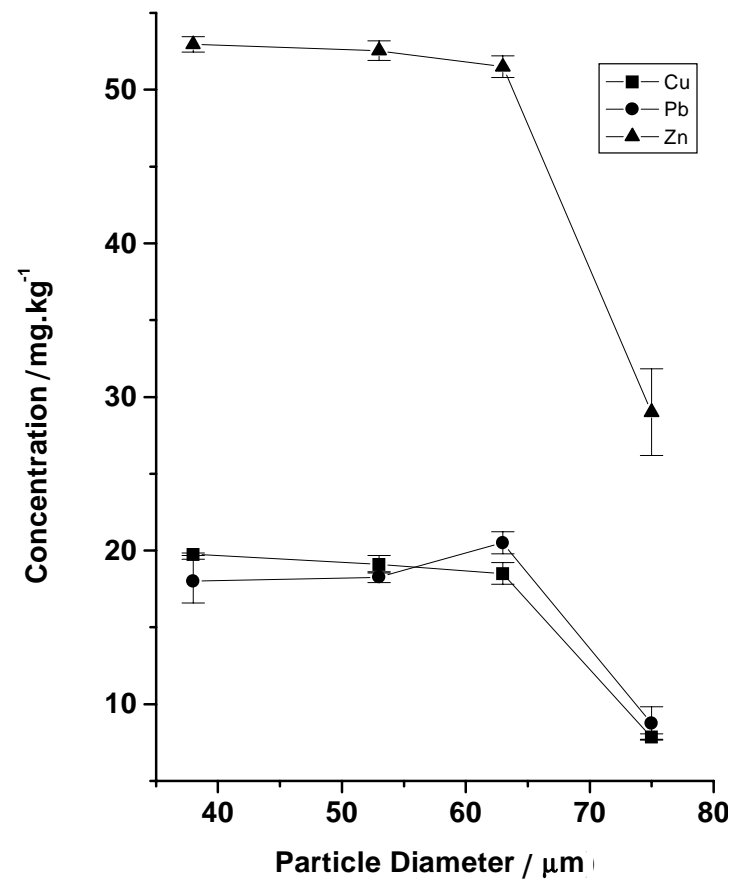

Figure 1. Effect of particle size on the analytical results for $\mathrm{Cu}, \mathrm{Pb}$ and $\mathrm{Zn}$.

using acid solutions ${ }^{29,30}$. In this study the sediment was suspended in nitric acid due to its well-known performance when flame atomic absorption spectrometry is used.

The slurry was prepared in the absence and presence of nitric acid, up to the $6.0 \mathrm{~mol} \mathrm{~L}^{-1}$. Higher nitric acid concentrations were not used due to acid consumption to perform the slurries and to maintain acceptable safety conditions. These considerations are more important if the method is proposed for a routine program.

In addition, good recoveries were achieved when $6.0 \mathrm{~mol} \mathrm{~L}^{-1}$ nitric acid concentration was used. It is interesting to point out that in all conditions the standards used to perform the analytical curve were prepared in the same acid concentration that slurries. In this way, possible nebulisation rate problems due to the density of the solutions were circumvented.

As shown in Figure 2, when water was used, the best results were obtained for copper, but with a recovery of only $c a .37 \%$. In the presence of diluted nitric acid an improvement was observed, leading to recoveries of $c a$. 60,70 and $80 \%$ for $\mathrm{Zn}, \mathrm{Pb}$ and $\mathrm{Cu}$, respectively. It was also observed that when nitric acid was employed in the 2.0 - $4.0 \mathrm{~mol} \mathrm{~L}^{-1}$ concentration range, the analytical signal remained almost constant for all the elements. On the other hand, the recoveries for all the elements studied were considered satisfactory at $6.0 \mathrm{~mol} \mathrm{~L}^{-1}(\mathrm{v} / \mathrm{v}) \mathrm{HNO}_{3}$ plus $2 \%(\mathrm{w} / \mathrm{v})$ ammonium chloride. At this condition, recoveries of $c a .95 \%$ were achieved for $\mathrm{Zn}, \mathrm{Pb}$ and $\mathrm{Cu}$. It is important 
to note that the signal values obtained for the blanks were always negligible in these experiments.

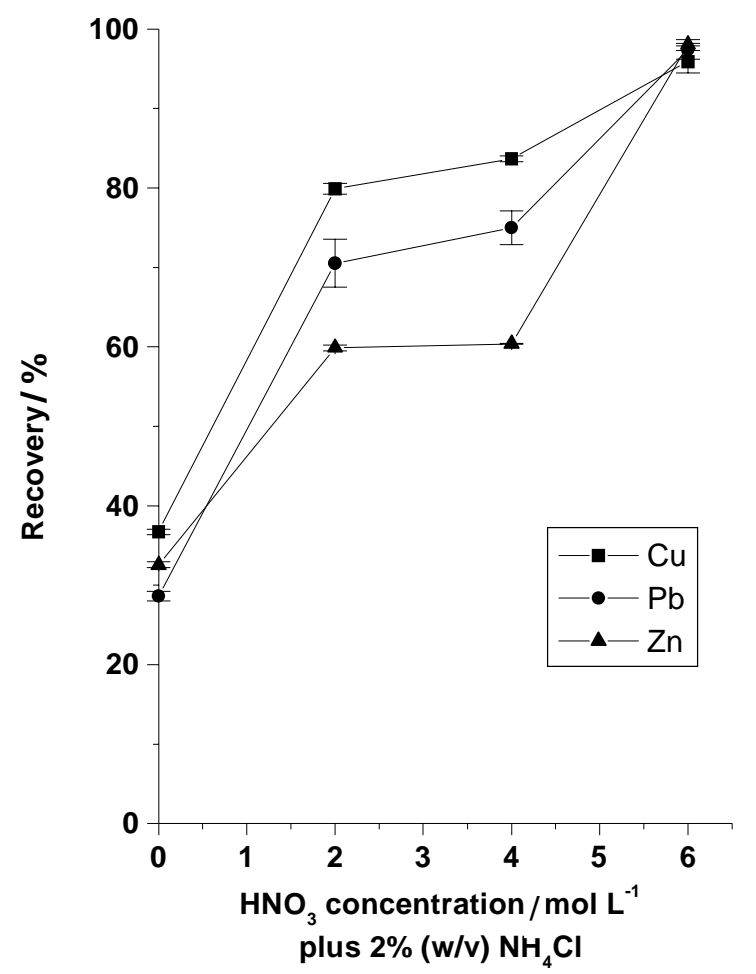

Figure 2. Effect of nitric acid concentration on the recoveries for $\mathrm{Cu}, \mathrm{Pb}$ and $\mathrm{Zn}$.

Another experiment was performed in order to verify if using $6.0 \mathrm{~mol} \mathrm{~L}^{-1}(\mathrm{v} / \mathrm{v}) \mathrm{HNO}_{3}+2 \%(\mathrm{w} / \mathrm{v}) \mathrm{NH}_{4} \mathrm{Cl}$ it would be possible to analyse only the slurry liquid phase, after filtration, and obtain accurate results. For $\mathrm{Cu}, \mathrm{Pb}$ and $\mathrm{Zn}$ decreases in the results of $c a .41,49$ and $75 \%$ were observed, respectively, indicating that total metal extraction does not occur, even using higher concentrations of nitric acid.

\section{Selectivity}

In this work, non-spectral interference for $\mathrm{Cu}, \mathrm{Zn}$ and $\mathrm{Pb}$ determinations were observed, once the total metal recoveries were not achieved. While positive or negative interference were achieved for $\mathrm{Cu}$ and $\mathrm{Zn}$ when different concomitants were studied (such as $\mathrm{Cr}, \mathrm{Ni}, \mathrm{Mn}, \mathrm{Al}, \mathrm{Ca}, \mathrm{K}$, $\mathrm{Na}, \mathrm{Cr}$ and $\mathrm{Fe}$ ), only positive interference was observed for $\mathrm{Pb}$, mainly for higher concentrations. Due to the complexity of matrix (slurries) and no data existence in the literature according to metals atomisation from slurries in flame, is not possible to make any statement related to the interference observed. Some hypothesis, however, can be made. Rubeska and Pelikánová 33 try to explain the enhance in the absorbance through heterogeneous reactions in flame spectrometry. The authors attributed this behaviour due to dry aerosol particle enters the flame, being heated and forming oxide species. Simultaneously, reduction by carbon containing species in the flame gases begins. In this way, the kinetics of two simultaneous reactions (vaporisation and reduction) take place for metal atomisation, increasing the absorbance of the results.

Despite the fact of the better explanation for the interference observed, we try to overcome this problem and improve the recoveries, using ammonium chloride as releasing agent ${ }^{31,32}$. It increases the volatility of metals, since their ammonium salts decompose at temperature lower than $400{ }^{\circ} \mathrm{C}$. This procedure was already successfully applied in a previous work ${ }^{34}$.

Concomitant effects were studied employing solutions containing $\mathrm{Cu}, \mathrm{Pb}$ or $\mathrm{Zn}$ in concentrations of 200, 230 and $980 \mu \mathrm{g} \mathrm{L}^{-1}$, respectively. These solutions were prepared in the presence of $6.0 \mathrm{~mol} \mathrm{~L}^{-1}(\mathrm{v} / \mathrm{v})$ nitric acid plus $2 \%(\mathrm{w} / \mathrm{v})$ ammonium chloride and spiked with the concomitants in the concentration ranges given for the certified reference material (Estuarine Sediment). $\mathrm{Cu}, \mathrm{Pb}$ and $\mathrm{Zn}$ were considered concomitants due to the monoelemental determination.

The recoveries for $\mathrm{Zn}$ and $\mathrm{Pb}$ were not affected by any added ions. In the determination of $\mathrm{Cu}$, a depression of $c a$. $14 \%$ in the analytical signal was observed only in the presence of $1.5 \mathrm{mg} \mathrm{L}^{-1} \mathrm{Cr}(\mathrm{VI})$. However, this interference was not observed when a real sample was analysed. Probably the interactions occurring among the foreign ions were responsible for the elimination of the interference effect when more than one species is present in the same solution.

\section{Analytical performance}

The direct introduction of the slurry sediment samples into a FAAS nebuliser for the determination of $\mathrm{Zn}, \mathrm{Cu}$ and $\mathrm{Pb}$ presented no problem related to capillary clogging. The reason for that is the fact that because between samples, a cleaning step, consisting of nebulisation of a nitric acid solution was performed. In this way, after on $8 \mathrm{~h}$ working period, only slight variation in the slopes of the calibration curves ( $c$. 8\%) was detected.

The analytical parameters obtained in the $\mathrm{Cu}, \mathrm{Pb}$ and $\mathrm{Zn}$ determinations with the proposed slurry sampling are described in Table 1 . The precision of the method was good (RSD less than 5\%). The detection and quantification limits $^{35}$ for metals present in the sediment itself ranged from 0.3 to 2.2 and from 0.9 to $7.4 \mu \mathrm{g} \mathrm{g}^{-1}$, respectively.

The results obtained were in agreement with the certified values (see Table 2), with a $t$-test showing no significant differences at the $95 \%$ confidence level. The accuracy was checked by certified reference material and by an alternative procedure (microwave oven digestion). 
Table 1. Analytical characteristics for $\mathrm{Cu}, \mathrm{Pb}$ and $\mathrm{Zn}$ in the slurry sampling.

\begin{tabular}{ccccc}
\hline Element & $\begin{array}{c}\text { Linear range } \\
\left(\mu \mathrm{g} \mathrm{L}^{-1}\right)\end{array}$ & $\begin{array}{c}\text { Correl. } \\
\text { Coef. }(\mathrm{r})\end{array}$ & $\begin{array}{c}\mathrm{DL}^{*} \\
\left(\mu \mathrm{g} \mathrm{L}^{-1}\right)\end{array}$ & $\begin{array}{c}\mathrm{QL}^{* *} \\
\left(\mu \mathrm{g} \mathrm{L}^{-1}\right)\end{array}$ \\
\hline $\mathrm{Cu}$ & $100-2000$ & 0.995 & 17.3 & 57.7 \\
$\mathrm{~Pb}$ & $200-2000$ & 0.997 & 44.0 & 148.0 \\
$\mathrm{Zn}$ & $100-1000$ & 0.999 & 5.7 & 18.9 \\
\hline *DL: detection limit $^{35}(\mathrm{n}=10) ;$ **QL: quantification limit $^{35}(\mathrm{n}=10)$
\end{tabular}

Table 2. Analytical results for $\mathrm{Cu}, \mathrm{Pb}$ and $\mathrm{Zn}$ in the certified material*, after mineralisation $(n=5)$, and as slurry $(n=5)$.

\begin{tabular}{llccc}
\hline Sample & Element & $\begin{array}{c}\text { Certified values } \\
\left(\mathrm{mg} \mathrm{kg}^{-1}\right)\end{array}$ & $\begin{array}{c}\text { Mineralised } \\
\text { sample } \\
\left(\mathrm{mg} \mathrm{kg}^{-1}\right)\end{array}$ & $\begin{array}{c}\text { Slurry } \\
\left(\mathrm{mg} \mathrm{kg}^{-1}\right)\end{array}$ \\
\hline Atibaia & $\mathrm{Cu}$ & - & $19.7 \pm 1.5$ & $21.0 \pm 2.0$ \\
River & $\mathrm{Pb}$ & - & $24.8 \pm 1.4$ & $24.0 \pm 1.2$ \\
Sediment & $\mathrm{Zn}$ & - & $53.3 \pm 4.0$ & $53.0 \pm 2.3$ \\
Estuarine & $\mathrm{Cu}$ & $10.01 \pm 0.34$ & $10.5 \pm 0.1$ & $9.7 \pm 0.5$ \\
Sediment & $\mathrm{Pb}$ & $11.7 \pm 1.2$ & $11.7 \pm 0.5$ & $11.7 \pm 0.5$ \\
$(1646 a)$ & $\mathrm{Zn}$ & $48.9 \pm 1.6$ & $44.0 \pm 1.8$ & $47.5 \pm 1.9$ \\
\hline * NIST SRM 1646a - Estuarine sediment & &
\end{tabular}

\section{Conclusions}

Using a simple slurry sampling method for the direct analysis, some advantageous results are achieved such as: low contamination due to less sample handling, no analyte losses and a low cost methodology for the $\mathrm{Cu}, \mathrm{Zn}$ and $\mathrm{Pb}$ determination in sediment samples.

\section{Acknowledgements}

The authors thank the Fundação de Amparo a Pesquisa do Estado de São Paulo (FAPESP, São Paulo, Brazil) and CNPq/PADCT-III (Brasília, Brazil) for financial support and the Conselho Nacional de Desenvolvimento Científico e Tecnológico (CNPq, Brasília, Brazil) for the fellowships of M.A.Z.A., W.F.J. and F.L.A. We also thank to Dr N. Miller-Ihli for critical comments and Prof. C. H. Collins and MSc. R. C. C. Micaroni for language assistance.

\section{References}

1. Hodges, L. Environmental Pollution, $2^{\text {nd }}$ ed., Rinehart and Winston, New York, 1977, p. 162-183.

2. Tipping, E.; Lofts, S.; Lawlor, A. J. Sci. Total Environ. 1998, 210/211, 63.

3. Jahiruddin, M.; Smart, R.; Wade, A. J.; Neal, C.; Cresser, M. S. Sci. Total Environ. 1998, 210/211, 53.

4. Alvarado, J.; Jaffé, R. J. Anal. At. Spectrom. 1988, 13, 37.

5. Willis, J. B. Anal. Chem. 1975, 47, 1752.

6. Klemm, W.; Bombach, G. Fresenius'J. Anal. Chem. 1995, 353, 12 .

7. Bermejo-Barrera, P.; Barciela-Alonso, C.; MoredaPiñeiro, J.; González-Sixto, C.; Bermejo-Barrera, A.
Spectrochim. Acta 1996, 51B, 1235.

8. Bermejo-Barrera, P.; Barciela-Alonso, C.; BermejoBarrera, A. Mikrochim. Acta 1996, 124, 251.

9. Bendicho, C.; de Loos-Vollebregt, M. T. C. J. Anal. At. Spectrom. 1991, 6, 353.

10. Miller-Ihli, N. J. Anal. Chem. 1992, 64, 964A.

11. Arruda, M. A. Z.; Gallego, M.; Valcárcel, M. Quim. Anal. 1995, 14, 17.

12. Brady, D. V.; Montalvo, J. G.; Jung, J.; Curran, R. A. At. Absorpt. Newslett. 1974, 13, 118.

13. Brady, D. V.; Montalvo Jr., J. G.; Glowacki, G.; Pisciotta, A. Anal. Chim. Acta 1974, 70, 448.

14. Sandoval, L.; Herraez, J. -C.; Steadman, G.; Mahan, K. I. Mikrochim. Acta 1992, 108, 19.

15. López-García, I.; Sánchez-Merlos, M.; HernándezCórdoba, M. Anal. Chim. Acta 1996, 328, 19.

16. López-García, I.; Sánchez-Merlos, M.; HernándezCórdoba, M. Spectrochim. Acta 1997, 52B, 437.

17. Fry, R. C.; Denton, M. B. Anal. Chem. 1977, 49, 1413.

18. Fuller, C. W. Analyst 1976, 101, 961.

19. Mohamed, N.; Fry, R. C. Anal. Chem. 1981, 53, 450.

20. O’Reilly, J. E.; Hicks, D. G. Anal. Chem. 1979, 51, 1905.

21. Stupar, J.; Ajlec, R. Analyst 1982, 107, 144.

22. Morales, A.; Pomares, F.; de la Guardia, M.; Salvador, A. J. Anal. At. Spectrom. 1989, 4, 329.

23. American Society for Testing and Materials, Standard practice for acid-extraction of Elements from Sediments Using Closed Vessel Microwave Heating, ASTM Designation D 5258-92, Philadelphia, PA, 1996, pp. 1-3 (CR-ROM).

24. Majidi, V.; Holcombe, J. A. Spectrochim. Acta 1990, $45 B, 753$.

25. Miller-Ihli, N. J. J. Anal. At. Spectrom. 1994, 9, 1129.

26. Januzzi, G. S. B.; Krug, F. J.; Arruda, M. A. Z. J. Anal. At. Spectrom. 1997, 12, 375.

27. Stephen, S. C.; Littlejohn, D.; Ottaway, M. Analyst 1985, 110, 1147.

28. Miller-Ihli, N. J. J. Anal. At. Spectrom. 1988, 3, 73.

29. López-García, I.; Arroyo-Cortéz, J.; HernándezCórdoba, M. Talanta 1993, 40, 1677.

30. Bautista, M. A.; Pérez-Sirvent, C.; López-García, I.; Hernández-Córdoba, M. Fresenius' J. Anal. Chem. 1994, 350, 359.

31. Price, W. J. Analytical Atomic Spectrometry, Heyden \& Sons LTD, $2^{\text {nd }}$ ed., London, 1978, p. 87-90.

32. Ng, K. C.; Caruso, J. A. Analyst 1983, 198, 476.

33. Rubeska, I.; Pelikánová, M. Spectrochim. Acta 1978, $33 B, 301$.

34. Alves, F. L.; Jardim, W. F.; Cadore, S.; Smichowski, P.; Marrero, J.; Arruda, M. A. Z. Quim. Nova, in press.

35. Analytical Methods Committee Analyst 1987, 112, 199. 